\title{
Perbedaan Penurunan Suhu Tubuh Anak Bronchopneumonia yang diberikan Kompres Hangat di Axilla dan Frontal
}

\author{
Rahmawati $^{1}$, Sari Fatimah ${ }^{2}$, Ikeu Nurhidayah ${ }^{2}$ \\ ${ }^{1}$ RSUP Dr. Hasan Sadikin, ${ }^{2}$ Fakultas Keperawatan Universitas Padjadjaran \\ E-mail:rahmawati712@yahoo.co.id
}

\begin{abstract}
Abstrak
Bronchopneumonia pada anak saat ini menjadi penyakit yang paling sering terjadi pada anak. Masalah keperawatan utama yang terjadi pada anak dengan pneumonia adalah terjadinya demam yang sangat berbahaya jika tidak ditangani dengan tepat. Tujuan penelitian untuk mengetahui perbedaan penurunan suhu tubuh pada anak demam dengan bronchopneumonia yang diberikan intervensi kompres hangat di axilla dan frontal di Ruang Anak RS "X". Desain yang digunakan dalam penelitian ini adalah kuasi eksperimen dengan rancangan pretest and posttest two group before after design. Sampel berjumlah 30 orang dengan usia 0-12 bulan, diambil secara purposive sampling. Alat ukur yang digunakan termometer digital. Analisis data dilakukan dengan dependent sample t test dan independent sample $t$ test. Hasil penelitian menunjukkan rata-rata suhu tubuh pada anak demam dengan bronchopneumonia sebelum diberikan intervensi kompres hangat di daerah axilla $38,51^{\circ} \mathrm{C}$ sedangkan di frontal $38,34^{\circ} \mathrm{C}$. Rata- rata suhu tubuh setelah diberikan intervensi di axilla $37,89^{\circ} \mathrm{C}$ dan di frontal $37,98^{\circ} \mathrm{C}$. Rata-rata penurunan suhu tubuh setelah diberikan intervensi di axilla $0.62^{\circ} \mathrm{C}$ sedangkan di daerah frontal $0.36^{\circ} \mathrm{C}$ (nilai $\mathrm{p}=0.000 ; \alpha=0.05$ ), sehingga dapat disimpulkan ada perbedaan yang signifikan antara pemberian kompres hangat di axilla dan di frontal terhadap penurunan suhu tubuh pada anak demam. Saran berdasarkan hasil penelitian, pemberian kompres hangat di axilla dapat dijadikan intervensi dalam menurunkan suhu tubuh anak yang mengalami demam.
\end{abstract}

Kata kunci: Axilla, bronchopneumonia, demam, frontal, kompres hangat.

\section{The Differences Between Warm Compress in Frontal and Axilla to Reduce Fever in Children with Bronchopneumonia}

\begin{abstract}
Bronchopneumonia is the most common diseases in children. The primary nursing problems occurred in children with bronchopneumonia is fever. This could be danger if could not treated appropriately. The aimed of this study was to identified the differences between warm compress intervention in axilla and frontal to reduce fever in children with bronchopneumonia in hospital X in Bandung. The method used in this study was quasi experiment with two group pre and post test design. Purposive sampling was used as sampling technique in this study, with 30 respondents were participated in this study. Data was analysed using dependent $t$ test and independent $t$ test. Result of this study showed the average of body temperature in febrile children with bronchopneumonia before warm compress intervention in axilla is $38.51{ }^{\circ} \mathrm{C}$, while in the frontal $38.34^{\circ} \mathrm{C}$. The average of body temperature after a given intervention in the axilla is $37.89^{\circ} \mathrm{C}$, while in the frontal is $37.98^{\circ} \mathrm{C}$. There was a significant temperature's decreases between frontal and axilla after intervention $(p=0.000 ; \alpha=0.05)$. There was a significant difference between giving a warm compress in the axilla and in the frontal the decrease in body temperature in febrile children. Based on this study, it can be concluded axillary warm compress can be used as an effective intervention to reduce fever in children.
\end{abstract}

Key words: Axilla, bronchopneumonia, fever, frontal, warm compresses. 
Rahmawati: Perbedaan Penurunan Suhu Tubuh pada Anak dengan Bronchopneumonia

\section{Pendahuluan}

Bronchopneumonia pada anak saat ini menjadi penyakit yang paling sering terjadi. Insiden penyakit ini pada negara berkembang hampir $30 \%$ pada anak-anak di bawah umur tiga tahun dengan resiko kematian yang tinggi pada bayi yang berusia kurang dari dua bulan. Menurut laporan World Health Organization atau WHO (2010), sekitar 800.000 hingga satu juta orang meninggal dunia tiap tahun akibat pneumonia. Bahkan United Nation Children's Fund (UNICEF) dan WHO menyebutkan pneumonia sebagai penyebab kematian anak balita tertinggi, sehingga sampai sekarang bronchopneumonia masih menjadi masalah kesehatan di Indonesia.

Pada tahun 2005 WHO memperkirakan kematian balita akibat bronchopneumonia di seluruh dunia sekitar 19\% atau berkisar 1,62,2 juta. Sekitar $70 \%$ terjadi di negara-negara berkembang termasuk Indonesia. Angka kematian bronchopneumonia pada balita di Indonesia diperkirakan mencapai 21\% (The United Nation Children Fund, 2006). Adapun angka kesakitan diperkirakan mencapai 250 hingga 299 per 1000 anak balita setiap tahunnya. Di Jawa Barat, pada akhir tahun 2000, pneumonia mengakibatkan 150.000 bayi atau balita meninggal tiap tahun, atau 12.500 pasien per bulan. Berdasarkan Survei Kesehatan Rumah Tangga (SKRT) pada tahun 2001 kematian balita akibat pneumonia meningkat, berkisar antara $18,5 \%-38,8 \%$ dan menempati urutan kedua sebagai penyebab kematian di Indonesia.

Masalah keperawatan utama pada anak dengan pneumonia adalah terjadinya demam yang sangat berbahaya jika tidak ditangani dengan tepat. Demam adalah suatu keadaan terjadinya peningkatan suhu tubuh. Demam merupakan kondisi suhu tubuh diatas $37,5^{\circ} \mathrm{C}$, sedangkan keadaan hiperpireksia (demam tinggi) adalah kenaikan suhu tubuh sampai $41^{\circ} \mathrm{C}$ atau lebih (Thomson, 2009).

Demam dapat diasosiasikan dengan adanya infeksi didalam tubuh, efek toksik dalam tubuh, juga dihubungkan dengan konsep humoral akibat produksi cairan tubuh dan peningkatan aliran darah, yang selanjutnya akan memengaruhi pusat pengaturan suhu (Guyton \& Hall, 1997; Thompson, 2009). Demam juga berperan sebagai mekanisme adaptif. Pada keadaan ini, demam bermanfaat sebagai proses imun dan mengontrol termoregulasi agar tetap stabil. Namun demikian, demam juga dapat memberikan dampak negatif, karena akan mengakibatkan peningkatan metabolisme, kehilangan cairan dan elektrolit, nyeri kepala, nyeri sendi, lemah, perasaan tidak nyaman, kurang nafsu makan, susah tidur, dan gelisah. Kerusakan jaringan juga dapat terjadi bila suhu lebih tinggi dari $41^{\circ} \mathrm{C}$. Jaringan yang rentan mengalami kerusakan adalah susunan saraf pusat (otak) dan otot, yang biasanya muncul sebagai gejala kejang.

Kejang dapat terjadi sebagai akibat dari demam tinggi yang tidak ditangani secara dini sehingga menimbulkan hipoksia jaringan otak dan pada akhirnya terjadi kerusakan otak. Suhu badan yang tinggi menyebabkan otak menjadi sensitif dan mudah mengalami kematian sel. Suhu badan yang tinggi menyebabkan otak menjadi sensitif dan mudah mengalami kematian sel. Hal ini sangat berbahaya bagi pertumbuhan dan perkembangan otak. Suhu tubuh tinggi berbahaya karena mengakibatkan perdarahan lokal dan degenerasi parenkimatosa di seluruh tubuh, gangguan pada metabolisme seluler tubuh, khususnya gangguan pada enzim sebagai katalisis berbagai reaksi oksidasi kimia. Gangguan ini akan menyebabkan terganggunya fungsi sel.

Upaya yang dapat dilakukan untuk mengatasi demam menurut panduan dari Royal College of Nursing (RCN) (2008) adalah dengan melakukan berbagai intervensi diantaranya dengan pemberian cairan yang adekuat, external cooling, dan pemberian antipiretik. External cooling adalah cara untuk menurunkan suhu dengan melakukan berbagai tindakan dengan prinsip radiasi membuka baju dan selimut; konduksi dengan memberikan pakaian yang tidak dingin dan melakukan kompres hangat, konveksi dengan melakukan fanning (menggunakan kipas angin), dan evaporasi. (Potter \& Perry, 2009; RCN, 2008). Anak tidak perlu diberikan kaos kaki dan penutup kepala, karena akan menghambat evaporasi tubuh dan menghambat penurunan suhu tubuh anak (RCN, 2008). Anak yang sedang demam juga harus diberikan asupan cairan yang adekuat. Intervensi selanjutnya adalah 
Rahmawati: Perbedaan Penurunan Suhu Tubuh pada Anak Demam dengan Bronchopneumonia

pemberian antipiretik. Antipiretik berperan untuk menurunkan set point hipothalamus. Beberapa penelitian menyarankan bahwa pemberian antipiretik sebaiknya disertai dengan kompres hangat untuk dapat menurunkan suhu tubuh secara optimal.

Ada beberapa cara penurunan panas seperti kompres menggunakan alkohol maupun es, namun cara ini sudah tidak direkomendasikan lagi. Pemberian kompres dengan alkohol berbahaya karena alkohol bersifat mudah menguap sehingga dapat terhirup oleh anak (Potter \& Perry, 2009). Hal ini juga sangat berbahaya karena dapat menyebabkan gangguan pada susunan saraf pusat (Hartono, 2003).

Pemberian kompres dengan air es juga tidak dianjurkan lagi karena tidak efektif untuk menurunkan suhu tubuh pada anak yang sedang mengalami demam. Penelitian yang sudah dilakukan sebelumnya membandingkan antara pemberian kompres hangat dan dingin. Hasil penelitian tersebut menunjukan bahwa kompres hangat lebih efektif daripada pemberian kompres dingin. Kompres dingin dapat menyebabkan perpindahan panas dari tubuh ke lingkungan sehingga justru akan meningkatkan kehilangan panas ke lingkungan dan menyebabkan terjadinya vasokontriksi pembuluh darah. Oleh karena itu kompres dingin tidak direkomendasikan untuk intervensi pada anak dengan demam, namun mungkin masih digunakan sebagai intervensi untuk menangani trombophlebitis (Potter \& Perry, 2008; Hartono, 2003).

External cooling merupakan salah satu tindakan untuk menurunkan demam. External cooling dilakukan dengan menggunakan kompres hangat sangat dianjurkan untuk mengatasi demam. Tindakan ini bermanfaat untuk melebarkan pembuluh darah dan mempercepat pertukaran panas antara tubuh dengan lingkungan, serta menurunkan suhu tubuh pada bagian perifer.

Intervensi pemberian kompres hangat dalam menangani demam dapat dilakukan pada beberapa area permukaan tubuh. Kompres hangat dapat diberikan di daerah temporall frontal (dahi), axilla (ketiak), leher (servikal) dan inguinal (lipatan paha) (Potter \& Perry, 2008). Penelitian yang pernah dilakukan sebelumnya adalah perbedaan efek teknik pemberian kompres hangat pada daerah axilla dan dahi terhadap penurunan suhu tubuh pada pasien dengan demam. Penelitian ini dilakukan pada pasien dewasa dengan menggunakan termometer digital (Nurwahyuni, 2010). Hasil penelitian tersebut menunjukan adanya perbedaan efek teknik pemberian kompres hangat pada daerah axilla dan frontal terhadap penurunan suhu tubuh. Penelitian untuk mengetahui perbedaan penurunan suhu tubuh pada pasien anak demam dengan bronchopneumonia yang diberi intervensi kompres hangat di axilla dan di frontal masih belum dilakukan.

Pemberian kompres hangat pada daerah yang mempunyai vaskular yang banyak maka akan memperluas daerah vasodilatasi, selanjutnya vasodilatasi yang kuat pada kulit akan memungkinkan percepatan perpindahan panas dari tubuh ke kulit, hingga delapan kali lipat lebih banyak (Tamsuri, 2006). Kenyataan yang ditemukan di lapangan untuk pemberian kompres hangat kebanyakan dilakukan di daerah dahi yang sebenarnya pemberian kompres di dahi lebih dimaksud untuk mengurangi stres daripada menurunkan demam anak (Widjaja, 2001).

RCN (2008) menekankan untuk terus melakukan penelitian guna mencari evidence based mengenai cara pelaksanaan kompres hangat untuk menurunkan demam secara tepat serta menghasilkan sebuah konsensus terkait pelaksanaan intervensi keperawatan dalam hal penanganan demam pada anak dengan bronchopneumoni.

Data dari rekam medik di Ruang Anak RS " $X$ " Bandung selama bulan JanuariDesember 2011 didapatkan jumlah pasien demam dengan bronchopneumoni sebanyak 504 orang. Menurut data di ruangan didapatkan bahwa kasus bronchopneumonia merupakan kasus tertinggi pada anak yang dirawat di ruangan perawatan anak di RS " $X$ ". Usia penderita demam pada bronchopneumonia yang dirawat di ruang anak pada umumnya anak usia satu bulan sampai 12 bulan, oleh karena itu subjek penelitian yang diambil pada penelitian ini adalah anak usia satu bulan sampai 12 bulan karena pada usia tersebut sistem termogulasi belum matang.

Berdasarkan informasi dari ruangan didapatkan bahwa saat ini perawat masih melakukan intervensi penurunan panas secara 
Rahmawati: Perbedaan Penurunan Suhu Tubuh pada Anak Demam dengan Bronchopneumonia

bervariasi, misalnya menggunakan kompres hangat di axilla, kompres hangat di frontal, dan kompres dingin di frontal. Mengenai intervensi penurunan suhu tubuh pada anak demam dengan bronchopneumonia yang telah dilakukan di ruangan masih belum terukur secara jelas dan akurat.

Demam pada anak perlu ditangani dengan tepat, apabila tindakan dalam mengatasi demam pada anak tidak tepat dan lambat maka akan mengakibatkan pertumbuhan dan perkembangan anak terganggu. Demam dapat membahayakan keselamatan anak jika tidak ditangani dengan cepat dan tepat serta akan menimbulkan komplikasi lain seperti, hipertermi, kejang, dan penurunan kesadaran. Penanganan yang cepat dan tepat akan meminimalisir keadaan yang membuat suhu tubuh anak semakin tinggi atau keadaan lainnya yang dapat membahayakan anak (Widjaja, 2001). Oleh karena itu, dalam mempertimbangkan pentingnya penanganan demam dan tindakan mandiri perawat dalam intervensi keperawatan, peneliti tertarik melakukan penelitian mengenai perbedaan penurunan suhu tubuh pada anak demam dengan bronchopneumonia yang telah diberikan intervensi kompres hangat di daerah axilla dan frontal di Ruang Anak RS "X".

\section{Metode Penelitian}

Desain yang digunakan dalam penelitian ini adalah kuasi eksperimen dengan rancangan pretest and posttest two group before after design. Cara pengambilan sampel dilakukan dengan teknik purposive sampling dengan kriteria inklusi klien bronchopneumonia dengan demam $\left(>37,5^{\circ} \mathrm{C}\right)$, kriteria ekslusif adalah klien dengan peningkatan tekanan intrakranial. Jumlah sampel sebanyak 30 orang responden. Pengukuran suhu tubuh menggunakan termometer digital yang sudah divalidasi sebelumnya. Analisis data menggunakan dependent $t$ test dan independent $t$ test. Pengambilan data pada penelitian ini memperhatikan prinsip etika selama penelitian. Responden yang terlibat dalam penelitian ini sebelumnya telah mendapatkan informed consent. Responden dibagi dalam dua kelompok, yakni kelompok I terdiri dari responden yang mendapatkan intervensi kompres hangat di area axilla dan kelompok II yaitu responden yang mendapatkan intervensi kompres hangat di frontal. Penelitian ini dilakukan selama satu bulan, di Ruang Perawatan Anak di RS ' $\mathrm{X}$ ' Kota Bandung.

\section{Hasil Penelitian}

Hasilpenelitian menunjukkan bahwa sebagian besar responden berusia satu sampai enam bulan. Rata-rata suhu tubuh pada kelompok kompres hangat di axilla sebelum intervensi adalah $38,51^{\circ} \mathrm{C}(\mathrm{SD} 0.480)$, sedangkan ratarata suhu tubuh sebelum intervensi di frontal $38,34^{\circ} \mathrm{C}$ (SD 0.554) (Tabel 1).

Pada Tabel 2, dapat dilihat rata-rata suhu tubuh setelah diberikan intervensi kompres hangat di axilla adalah $37,89^{\circ} \mathrm{C}$ (SD 0.484), sedangkan rata-rata suhu tubuh setelah diberi intervensi pada kelompok kompres hangat di frontal adalah $37,98^{\circ} \mathrm{C}(\mathrm{SD} 0.487)$.

Pada tabel 3 dapat dilihat bahwa pada kelompok intervensi di axilla, rata-rata suhu tubuh sebelum diberi intervensi adalah $38,513{ }^{\circ} \mathrm{C}$ dan setelah diberi intervensi adalah $37,89^{\circ} \mathrm{C}(\mathrm{SD} 0.484, p=0.000, \alpha=0.05)$, maka dapat disimpulkan bahwa terdapat perbedaan yang signifikan rata-rata suhu tubuh sebelum dan sesudah diberi kompres hangat pada axilla. Sedangkan pada kelompok yang diberikan intervensi di frontal, didapatkan rata-rata suhu tubuh sebelum intervensi adalah $38,34^{\circ} \mathrm{C}$ (SD 0.554$)$ dan rata-rata suhu tubuh setelah intervensi adalah $37,98^{\circ} \mathrm{C}$

Tabel 1 Distribusi Suhu Tubuh Sebelum Diberikan Intervensi Kompres Hangat pada Kelompok I dan Kelompok II

\begin{tabular}{lcccc}
\hline \multicolumn{1}{c}{ Kelompok } & Rata-rata & Std Deviasi & Nilai Min & Nilai Max \\
\hline & & OC & 0C & 0C \\
Kelompok I & 38,513 & 0.480 & 37,7 & 39,3 \\
Kelompok II & 38,347 & 0.554 & 37,6 & 39,4 \\
\hline
\end{tabular}

Volume 1 Nomor 3 Desember 2013 
Rahmawati: Perbedaan Penurunan Suhu Tubuh pada Anak Demam dengan Bronchopneumonia

Tabel 2 Distribusi Suhu Tubuh Setelah Diberikan Intervensi Kompres Hangat pada Kelompok I dan Kelompok II

\begin{tabular}{lcccc}
\hline \multicolumn{1}{c}{ Kelompok } & Rata- rata & Std Deviasi & Nilai Min & Nilai Max \\
\hline Kelompok I & 37,893 & 0.484 & 37,0 & 38,7 \\
Kelompok II & 37,980 & 0.487 & 37,5 & 38,8 \\
\hline
\end{tabular}

(SD 0.487) dengan nilai $p=0.000(\alpha=0.05)$. Dengan demikian dapat disimpulkan terdapat perbedaan penurunan rata-rata suhu tubuh sebelum dan sesudah di beri kompres hangat di daerah frontal secara signifikan.

Pada tabel 4 di atas didapatkan data bahwa terdapat penurunan suhu tubuh sebelum dan sesudah intervensi pada kelompok kompres hangat di axilla, dengan rata-rata $0.62^{\circ} \mathrm{C}$, (SD: 0.101), sedangkan pada kelompok kompres hangat di frontal terjadi penurunan dengan rata-rata $0.366^{\circ} \mathrm{C}$ (SD: 0.149 ). Hasil penelitian menunjukkan nilai $p=0.000$ pada $\alpha=0.05$, sehingga dapat disimpulkan terdapat perbedaan antara pemberian kompres hangat di bagian axilla (kelompok I) dan pemberian kompres hangat di frontal (kelompok II) terhadap penurunan suhu tubuh. Berdasarkan tabel tersebut dapat dilihat bahwa pemberian kompres hangat di axilla dapat menurunkan suhu tubuh lebih besar dibandingkan dengan pemberian kompres hangat di frontal.

\section{Pembahasan}

Peningkatan suhu tubuh pada anak usia satu bulan sampai 12 bulan yang mengalami demam $>38,5^{\circ} \mathrm{C}$ dapat membahayakan dan merupakan kondisi yang kritis (Simon,
Fleischack, \& Hartman, 2006). Pemberian kompres hangat di axilla dapat menurunkan suhu tubuh anak sebesar $0.620^{\circ} \mathrm{C}$. Hal ini sangat bermanfaat sekali dikarenakan pada usia tersebut sistem termogulasi belum matang dan ada kecenderungan untuk mengarah pada kejang demam. Pemberian kompres hangat pada area permukaan tubuh akan memberikan sinyal ke hipotalamus. Ketika reseptor yang peka terhadap panas di hipotalamus terangsang, selanjutnya sistem effektor mengeluarkan sinyal yang memulai pengeluaran keringat dan vasodilatasi perifer. Terjadinya vasodilatasi ini menyebabkan pembuangan atau kehilangan energi/ panas melalui keringat. Hal ini selanjutnya akan menyebabkan penurunan suhu tubuh sehingga mencapai keadaan normal kembali (Smeltzer \& Bare, 2002).

Pemberian kompres hangat pada daerah axilla dapat menurunkan suhu tubuh lebih besar dibandingkan dengan pemberian kompres hangat di frontal. Hal ini terjadi karena di daerah axilla terdapat banyak pembuluh darah yang akan mengalami vasodilatasi. Vasodilatasi yang kuat pada kulit memungkinkan percepatan perpindahan panas dari tubuh ke kulit sebanyak delapan kali lipat. Kompres yang dilakukan pada daerah axilla lebih efektif dibandingkan

Tabel 3 Penurunan Suhu Tubuh pada Kelompok 1 Sebelum dan Sesudah Diberikan Intervensi Kompres Hangat

\begin{tabular}{lccc}
\hline & Rata-rata suhu & Std Deviasi & P value (95\% CI) \\
\hline $\begin{array}{l}\text { Kelompok Intervensi di Axilla } \\
\text { Sebelum perlakuan }\end{array}$ & 38,513 & 0.480 & \\
& & & 0.000 \\
$\begin{array}{l}\text { Setelah perlakuan } \\
\text { Kelompok Intervensi di Frontal }\end{array}$ & 37,893 & & \\
Sebelum perlakuan & 38,347 & 0.554 & 0.000 \\
\hline Sesudah perlakuan & 37,980 & 0.487 & \\
\hline
\end{tabular}


Rahmawati: Perbedaan Penurunan Suhu Tubuh pada Anak Demam dengan Bronchopneumonia

Tabel 4 Perbedaan Penurunan Suhu Tubuh Sebelum dan Setelah Diberikan Intervensi Kompres Hangat

\begin{tabular}{lcccc}
\hline \multicolumn{1}{c}{ Kelompok } & Penurunan suhu & Std Deviasi & SE & $P$ \\
\hline \multirow{2}{*}{ Kelompok I } & 0.620 & $\mathbf{( 0 C )}$ & & \\
& & 0.101 & 0.026 & \\
Kelompok II & 0.366 & 0.149 & 0.038 & 0,000 \\
\hline
\end{tabular}

kompres di daerah dahi karena pada daerah axilla banyak terdapat pembuluh darah besar dan kelenjar keringat apokrin (Corwin, 2002).

Pemberian kompres hangat di frontal dapat menurunkan suhu tubuh akan menstimulasi hipotalamus yang merupakan pusat regulasi suhu tubuh sehingga akan terjadi penurunan suhu tubuh (RCN, 2008). Pengompresan di dahi lebih dimaksud untuk mengurangi stres dari pada menurunkan demam anak (Widjaja, 2001). Sedangkan kompres pada daerah kepala tidak efektif karena terhalang tulang tengkorak (RCN, 2008). Pada kelompok kompres hangat di axilla dan di frontal responden diberikan tindakan selama 20 menit, sebagian besar responden mengalami penurunan suhu tubuh, sebagian responden merasa nyaman hingga tertidur saat dilakukan tindakan. Simon, dkk. (2006) mengatakan bahwa pemberian kompres hangat dapat meningkatkan kenyamanan dan menurunkan suhu tubuh.

Pada penelitian ini didapatkan penurunan suhu pada kelompok I adalah $0.620^{\circ} \mathrm{C}$ sedangkan pada kelompok II adalah $0.366^{\circ} \mathrm{C}$ menunjukkan bahwa terdapat penurunan yang signifikan. Penelitian yang dilakukan oleh Thompson (2009) yang membandingkan intervensi tepid sponge dengan pemberian parasetamol menunjukkan bahwa pada pasien yang mendapat tepid sponge terjadi penurunan suhu sebesar $0.78^{\circ} \mathrm{C}$ pada 30 menit pertama setelah mendapatkan tepid sponge. Hasil penurunan suhu pada penelitian ini lebih kecil dari penelitian yang dilakukan oleh Thompson (2009). Hal ini dikarenakan pada penelitian ini kompres hangat hanya dilakukan di axilla sedangkan pada penelitian Thompson (2009) tindakan yang dilakukan adalah tepid sponge pada seluruh area tubuh.

Tepid sponge menyebabkan vasodilatasi pembuluh darah dan mempercepat pertukaran panas (heat exchange) antara tubuh dengan lingkungan, serta menurunkan suhu tubuh perifer. Tepid sponge bermanfaat untuk menurunkan suhu tubuh pada 15-30 menit pertama setelah intervensi dan hal tersebut berguna untuk mencegah terjadinya kejang pada anak. Pada penelitian yang dilakukan Thompson (2009) intervensi sponging dilakukan dengan sponge/ washlap yang telah dibasahi oleh air hangat mulai dari muka, leher, lengan, dan tangan (dimulai dari area akromion, jari-jari sampai axilla) pada kedua tangan, kemudian washlap hangat diselipkan pada axilla selama satu menit, setelah itu lakukan sponging pada kaki mulai dari bagian lateral lipat paha kemudian ke arah lipat paha, washlap hangat kemudian dibiarkan pada lipatan paha selama satu menit. Abdomen dan punggung juga diberikan washlap hangat. Setelah semua prosedur tepid sponge selesai, kemudian seluruh tubuh pasien dikeringkan dengan handuk kering dan dipakaikan baju yang nyaman. Oleh karena itu hasil penelitian Thompson (2009) ini memberikan penurunan suhu tubuh yang lebih besar daripada penelitian ini. Pada penelitian ini, intervensi yang dilakukan dengan kompres hangat hanya dilakukan di axilla, sehingga penurunan suhu tubuh yang didapatkan lebih kecil daripada penelitian yang dilakukan oleh Thompson (2009).

Perawat sebagai salah satu tenaga kesehatan yang berperan dalam memberikan asuhan keperawatan pada anak harus dapat melakukan pengelolaan deman anak secara tepat. Salah satu intervensi mandiri yang dapat dilakukan yaitu dengan melakukan kompres hangat pada tubuh terutama pada area axilla atau lipatan inguinal. Perawat juga harus berkolaborasi dengan dokter dalam penanganan demam secara farmakologis dengan memberikan obat antipiretik yang aman bagi anak. Hasil penelitian ini diharapkan dapat menjadi 
Rahmawati: Perbedaan Penurunan Suhu Tubuh pada Anak Demam dengan Bronchopneumonia

salah satu evidence based yang dapat digunakan dalam pengembangan intervensi keperawatan penanganan demam pada anak. Penelitian ini juga diharapkan dapat menjadi dasar bagi penelitian selanjutnya dalam mengembangkan intervensi yang efektif dalam penanganan demam pada anak.

\section{Simpulan}

Penelitian diatas menunjukkan rata-rata suhu tubuh pada anak dengan bronchopneumonia sebelum dilakukan intervensi kompres hangat di daerah axilla adalah $38,513^{\circ} \mathrm{C}$ sedangkan di frontal adalah $38,34^{\circ} \mathrm{C}$. Rata-rata suhu tubuh pada anak dengan bronchopneumonia setelah diberikan intervensi kompres di axilla adalah $37,893^{\circ} \mathrm{C}$ sedangkan setelah diberikan intervensi kompres hangat di frontal adalah $37,98^{\circ} \mathrm{C}$. Rata-rata penurunan suhu tubuh pada anak demam dengan bronchopneumonia setelah diberikan intervensi pemberian kompres hangat di axilla adalah $0.62^{\circ} \mathrm{C}$. Rata-rata suhu tubuh pada anak demam dengan bronchopneumonia setelah diberikan intervensi kompres hangat di daerah frontal adalah $0.366^{\circ} \mathrm{C}$. Terdapat perbedaan yang signifikan terhadap penurunan suhu tubuh sebelum dan setelah intervensi pemberian kompres hangat di daerah axilla dan di fronta

Hasil penelitian ini diharapkan dapat menjadi salah satu evidence based yang dapat digunakan dalam pengembangan intervensi keperawatan dalam menangani anak demam dengan bronchopneumonia. Selanjutnya penelitian ini menyarankan untuk memberikan intervensi kompres hangat yang paling tepat dalam menangani demam pada anak.

\section{Daftar Pustaka}

Arikunto, S. (2002). Prosedur penelitian, suatu pendekatan praktek (Edisi revisi V). Jakarta: PT. Rineka Cipta.

Corwin, E .J. (2001). Buku saku patofisiologi. Jakarta: EGC.

Ganong, W. F., 2000. Fisiologi kedokteran. (Edisi ke-10). Jakarta: EGC.
Guyton, A.C. \& Hall, J.E. (1997). Buku ajar fisiologi kedokteran. Jakarta: ECG.

Hartono. (2003). Analisis data statistik penelitian. Yogyakarta: Pustaka Pelajar.

Hawkins, J. (2009). Supportive care: Managing febrile neutropenia. Pediatric Nursing, 21(4), 18-24.

Hockenberry, M.J., \& Wilson, D. (2009). Wong's nursing care infant and children. St Louis: Mosby Inc.

Ignatavicius, D. \& Linda W . (2002). Medical surgical nursing, critical thingking for colaborative care (4th ed.). New York: WB, Saunders Company.

Nurwahyuni, I. (2010). Perbedaan efek teknik pemberian kompres pada daerah axilla dan dahi terhadap penurunan suhu tubuh pada klien demam di ruang rawat inap RSUP dr Wahidin Sudirohusodo Makasar (Skripsi). Diakses dari http://myzona skripsi. com/2011/01/perbedaan-efek-teknik pemberian kompres.html.

Perry, A. \& Potter, P. (2002). Clinical nursing skil and techniques (5th ed.). St.Louis: Mosby Company.

Royal College of Nursing. (2008). Managing fever: Practice guide. Pediatric nursing, 20(8), 1-12.

Simon, A., Fleischack, G., \& Hartman, C. (2006). Meropenem versus ceftazidime as emphirical monotherapy in febrile neutropenia of pediatric patients with cancer. $J$ Antimicrob Chemother, 47, 841-853.

Smetlzer, S. \& Bare, G. (2002). Keperawatan medikal bedah. Jakarta: EGC.

Smith, S., F. (2004). Clinical nursing skill, bacis to advance skill (6th ed.). New Jersey: Pearson Prentice-Hall.

Survei Kesehatan Rumah Tangga.(1995). Badan litbang. Jakarta: Depkes RI.

Tamsuri, A. (2006). Tanda-tanda vital: Suhu 
Rahmawati: Perbedaan Penurunan Suhu Tubuh pada Anak Demam dengan Bronchopneumonia

tubuh. Jakarta: ECG.

Thompson, J. (2009). Fever: A concept analysis. J Adv Nurs, 2(4), 10-15. doi: $10.111 /$ j.1365-2648.2005.0.520.x.
Widjaja, M., C. (2001). Mencegah dan mengatasi demam pada balita.Jakarta:

Kawan Pustaka.

World Health Organization (WHO). (2010). World health statistics. 